Article

\title{
Evaluation of Regional Climate Models (RCMs) Performance in Simulating Seasonal Precipitation over Mountainous Central Pindus (Greece)
}

\author{
Stefanos Stefanidis ${ }^{1, *}$, Stavros Dafis ${ }^{2,3}$ (D) and Dimitrios Stathis ${ }^{1}$ \\ 1 Faculty of Forestry and Natural Environment, Aristotle University of Thessaloniki, \\ Laboratory of Mountainous Water Management and Control, 54124 Thessaloniki, Greece; dstatis@for.auth.gr \\ 2 National Observatory of Athens, Institute for Environmental Research and Sustainable Development, \\ I. Metaxa \&Vas. Pavlou, P. Penteli (Lofos Koufou), 15236 Athens, Greece; \\ sdafis@noa.gr or sdafis@lmd.polytechnique.fr \\ 3 LMD/IPSL, CNRS UMR 8539, École Polytechnique, Université Paris Saclay, ENS, PSL Research University, \\ Sorbonne Universités, UPMC Univ Paris 06, 91128 Palaiseau, France \\ * Correspondence: ststefanid@gmail.com; Tel.: +30-2310-992712
}

Received: 30 August 2020; Accepted: 30 September 2020; Published: 2 October 2020

check for updates

\begin{abstract}
During the last few years, there is a growing concern about climate change and its negative effects on water availability. This study aims to evaluate the performance of regional climate models (RCMs) in simulating seasonal precipitation over the mountainous range of Central Pindus (Greece). To this end, observed precipitation data from ground-based rain gauge stations were compared with RCMs grid point's simulations for the baseline period 1974-2000. Statistical indexes such as root mean square error (RMSE), mean absolute error (MAE), Pearson correlation coefficient, and standard deviation (SD) were used in order to evaluate the model's performance. The results demonstrated that RCMs fail to represent the temporal variability of precipitation time series with exception of REMO. Although, concerning the model's prediction accuracy, it was found that better performance was achieved by the RegCM3 model in the study area. In addition, regarding a future projection (2074-2100), it was highlighted that precipitation will significantly decrease by the end of the 21st century, especially in spring $(-30 \%)$. Therefore, adaption of mountainous catchment management to climate change is crucial to avoid water scarcity.
\end{abstract}

Keywords: precipitation; climate change; RCMs; mountainous area

\section{Introduction}

During the last decades, increasing water demand (population growth, urbanization, and industrialization) and recent global warming are making water a precious, but not always available, asset [1,2]. Especially, the Mediterranean climate favors the development of water scarcity [3,4], as the precipitation regime presents spatial and temporal variability [5-7]. Moreover, the Intergovernmental Panel on Climate Change (IPCC) Fifth Assessment Report [8] emphasizes that the Mediterranean basin is expected to be drier by the end of the 21st century and much warmer than the global mean [9]. The aforementioned changes will have environmental and economic impacts as they affect flooding [10], soil erosion [11,12], drought phenomena [13,14], agriculture [15,16], wildfires [17,18], and tourism $[19,20]$.

Precipitation is a key factor for the assessment of climate change impacts, due to its direct influence on water availability and natural hazards (floods, drought, landslides, etc.). Its spatial and temporal distribution is important to various scientific fields such as geography, hydrology, forest management, agriculture, ecology, and others [6,21,22]. Future projections are also essential 
for rational water resources management. Therefore, high spatial resolution spatial climate data are necessary for climate change impact assessment studies. For the Greek territory, located in the eastern Mediterranean, reducing monthly accumulated precipitations and more frequent extreme precipitation events, combined with increasing temperatures, are expected under future climate conditions [23-25].

Currently, general circulation models (GCMs) are the most advanced tools for the estimation of future climate changes in global scale. GCMs are numerical models representing physical processes in the atmosphere, ocean, cryosphere, and land surface, based on the principals of energy and water balance. They are tools for simulating climate responses in increasing concentrations of greenhouse gases and are able to provide assessments of climate change.

The spatial analysis of GCMs (200 to $300 \mathrm{~km}$ ) gives satisfactory results for the global circulation across the planet. However, they have been proved to be ineffective in simulating hydrological variables at the catchment-scale due to their coarse spatial resolution. In addition, they cannot accurately simulate regional scale phenomena due to local conditions and particularities, such as the complex topography, lakes, and small islands [26].

In order to meet the demands of hydrological impact assessment studies for regional precipitation, several downscaling techniques have been developed to bridge the gap between the large-scale GCM estimation and local needs. The downscaling techniques are divided into statistical [27,28] and dynamic $[29,30]$. The statistical methods use the observed relationships between large-scale circulation and the local climate, whereas dynamic methods use physically based regional climate models (RCMs). The main advantages of a statistical downscaling approach are low computational requirements, whereas dynamic downscaling is appreciated by researchers for its superiority of embracing more systematic characteristics in relation to topography and climatic dynamical processes. In recent years, several studies used RCMs in order to assess climate change effect on hydrology [31-35]. The effectiveness of these models is mostly dependent on their inputs, especially the past climate data [36]. The comprehension of the hydrological cycle components response to the climate variability has become more and more fundamental. Understandings of the uncertainties in future climate projections are of major interest. Therefore, the ability of RCMs to represent climate conditions should be examined prior to their use in impact assessment studies [37-39].

In the frame of the European Union (EU) funding project ENSEMBLE, a set of multi-model RCM simulations to characterize climate change in Europe with high spatial resolution $(25 \times 25 \mathrm{~km})$, were produced. There are many studies in Europe evaluating the ability of RCMs to represent precipitation [40-44]. It is noteworthy that most of these studies referred to plain areas and lowlands. Nevertheless, limited studies evaluate the performance of RCMs simulations in mountainous areas of the Mediterranean basin [45], while there is no such research for the mountainous ranges of Greece. Mountainous areas are of great interest for water resources management, since runoff generates and supplies (through catchments) lowlands with water.

This study aims to evaluate the performance of RCMs from the ENSEMBLE project in simulating the seasonal and annual precipitation over the mountainous range of Central Pindus (Greece) and quantify the effect of climate change on future precipitation.

\section{Materials and Methods}

Observations of monthly accumulations of precipitation data from 13 ground-based rain gauge stations over the mountainous range of Central Pindus (Greece) were used for the period 1974-2000. It is noteworthy that the study area has a dense network of rain gauge stations located in high elevation, in comparison with other areas within Greece. The data series are complete without missing values. The station data were checked for homogeneity using the Alexandersson [46] homogeneity test, on a monthly basis and for each station separately. The results verified that the data from all the stations are homogeneous. These stations are operated by the Ministry of Environment \& Energy (Agiofylo, Agnanta, Chrysomilia, Elati, Katafyto and Malakasi, Megali Kerasia, Platanousa, and Theodoriana), the Public Power Corporation (Mesochora, Polyneri, and Stournareika) and the University Forest 
Administration and Management Fund (Pertouli). The characteristics of the above-mentioned stations are given in the next table (Table 1).

Table 1. Characteristics of the rain gauge stations.

\begin{tabular}{ccccc}
\hline \multirow{2}{*}{ A/A } & Meteorological Station & \multicolumn{2}{c}{ Coordinates } & \multirow{2}{*}{ Elevation (m) } \\
\cline { 3 - 4 } & & Longitude $\left(^{\circ}\right)$ & Latitude $\left(^{\circ}\right)$ & \\
\hline 1 & Agiofylo & 21.34 & 39.52 & 580 \\
2 & Agnanta & 21.08 & 39.47 & 660 \\
3 & Chrysomilia & 21.3 & 39.36 & 910 \\
4 & Elati & 21.32 & 39.51 & 909 \\
5 & Katafyto & 21.28 & 39.38 & 1018 \\
6 & Malakasi & 21.17 & 39.47 & 850 \\
7 & Megali Kerasia & 21.49 & 39.75 & 509 \\
8 & Mesochora & 21.20 & 39.26 & 849 \\
9 & Pertouli & 21.28 & 39.33 & 1180 \\
10 & Polyneri & 21.22 & 39.34 & 802 \\
11 & Platanousa & 21.01 & 39.41 & 454 \\
12 & Stournareika & 21.29 & 39.28 & 761 \\
13 & Theodoriana & 21.2 & 39.43 & 941 \\
\hline
\end{tabular}

Additionally, precipitation data were derived from five (5) RCMs. Simulations were developed for the European ENSEMBLE project (http://ensembles-eu.metoffice.com/), with high spatial resolution $(25 \times 25 \mathrm{~km})$ under the A1B future emission scenario of the Special Report on Emissions Scenarios (SRES). The selected models were also driven by fifth-generation GCM ECHAM5-r3. The details of the RCMs used in this study are given in the following table (Table 2).

Table 2. The regional climate models (RCMs) used in this study.

\begin{tabular}{cccc}
\hline Acronym & Institute & Main Reference \\
\hline HIRHAM & DMI (Danish Meteorological Institute, Denmark) & [47] \\
RegCM3 & ICTP (The Abdus Salam International Center for Theoretical Physics, Italy) & [48] \\
RACMO2 & KNMI (Royal Netherlands Meteorological Institute, Netherlands) & [49] & [50] \\
REMO & MPI (Max-Planck-Institute for Meteorology, Germany) & [51] \\
RCA & SMHI (Swedish Meteorological and Hydrological Institute, Sweden) & \\
\hline
\end{tabular}

In order to evaluate the RCMs performance, simulated annual and seasonal precipitation values from the RMCs were compared with the observed records of precipitation from the nearest ground-based rain gauge stations over the baseline period 1974-2000 (Figure 1). The rain gauge within a $25 \mathrm{~km}$ radius and with an elevation difference of less than $200 \mathrm{~m}$ from a model grid point was considered as the nearest neighbor. With such an approach, the rain gauges used in this study lie on the same side of the Pindus' slopes and within comparable elevation as the RCMs grid points.

Initially, the statistical evaluation was presented with Taylor diagrams. These diagrams provide a way of graphically summarizing how closely a pattern (or a set of patterns) matches observations [52]. The similarity between two patterns was quantified in terms of their correlation and the normalized standard deviation. Furthermore, the root mean square error (RMSE) and mean absolute error (MAE) were used as evaluation indexes and presented in separate diagrams. The mathematical formulas of these indexes are given below:

$$
\begin{gathered}
R M S E=\sqrt{\frac{1}{n} \sum_{i=1}^{n}\left(y_{i}-x_{i}\right)^{2}} \\
M A E=\frac{1}{n} \sum_{i=1}^{n}\left|y_{i}-x_{i}\right|
\end{gathered}
$$


where $n$ is the number of observations, $x_{i}$ and $y_{i}$ are the observed and simulated values, respectively, for $i=1,2 \ldots n$. The RMSE gives the weighted variations (residuals) in errors between the simulated and observed values, while MAE measures the weighted average magnitude of the errors. Since the errors in RMSE are squared before they are averaged, the RMSE gives a relatively high weight to large errors. This means that the RMSE should be more useful when large errors are particularly undesirable. MAE is the most natural and unambiguous measure of average error magnitude [53-55]. RMSE, on the other hand, is one of the most widely used error measures. Both RMSE and MAE values were converted to percent RMSE (\%RMSE) and percent MAE (\%MAE) by dividing the RMSE or MAE by the means of observed values, in order to compare the model's performance between seasons [56]. It is noteworthy that the lower the value of \%RMSE and \%MAE, the more reliable the forecast is considered to be.

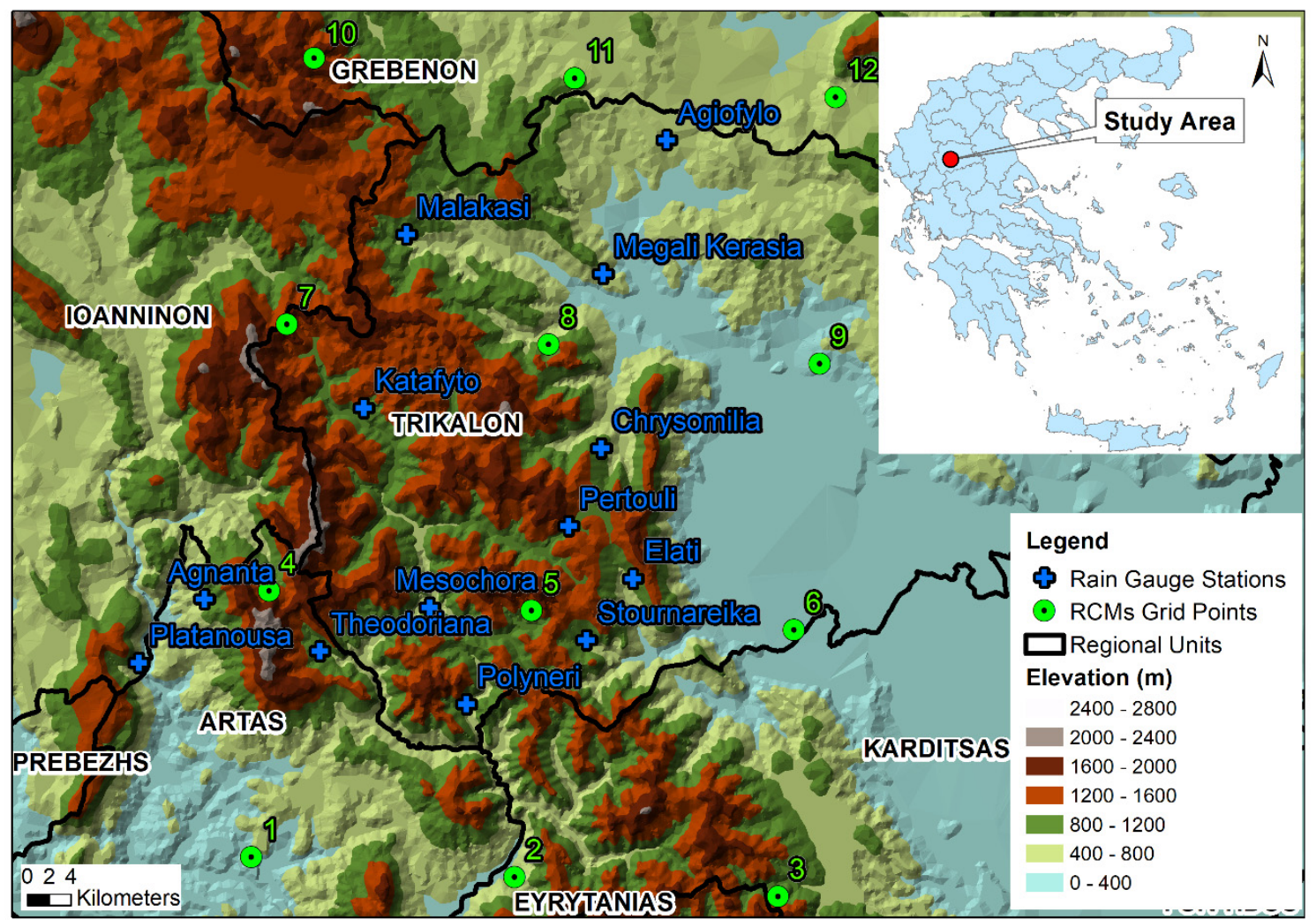

Figure 1. Location map of the rain gauge stations and RCMs grid points in the study area.

\section{Results}

Historical RCMs precipitation datasets were evaluated against the ground-based rain gauge stations for the period 1974-2000. An overview of the results for annual and seasonal precipitation is presented by Taylor diagrams (Figure 2).

The results showed low correlation for the majority of the RCMs for both annual and seasonal precipitation. It became clear that the better correlation coefficient was achieved by the REMO model followed by the RegCM3. Regarding the annual and autumn precipitation, the results better correlated with observations for the majority of the models, whereas the lowest coefficient correlation was found in summer precipitation. Concerning the variability of precipitation, the differences of the standard deviation values showed that the models did not manage to generate a low standard deviation sufficiently during the selected period. However, it should be mentioned that the REMO model presented better results, especially in summer, while the worst results were presented in autumn. To this end, it is obvious that RCMs lack the ability to realistically represent the temporal variability of precipitation time series. 


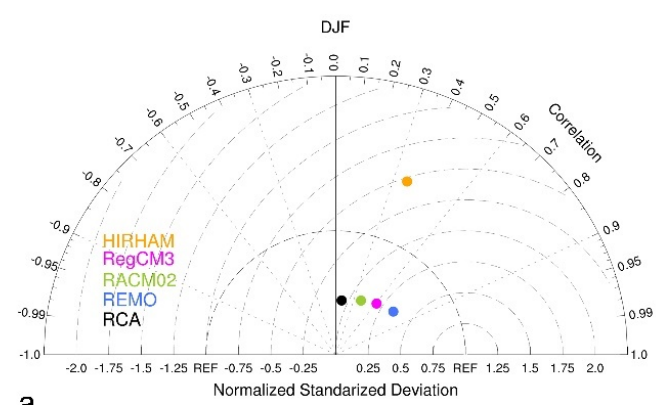

a

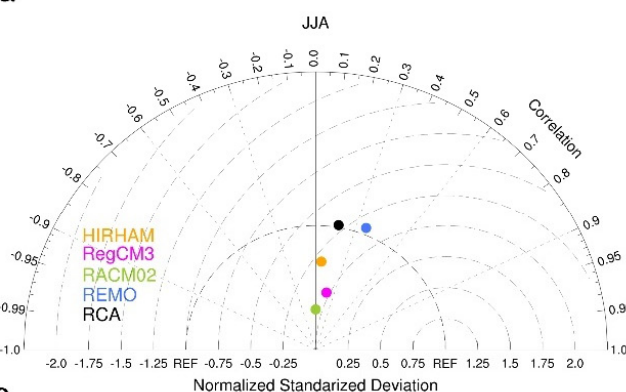

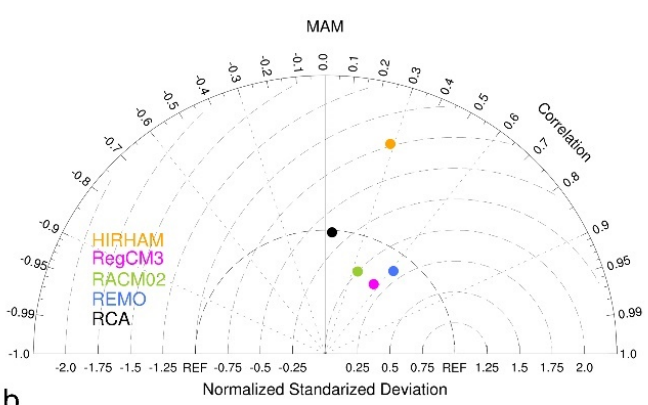

SON

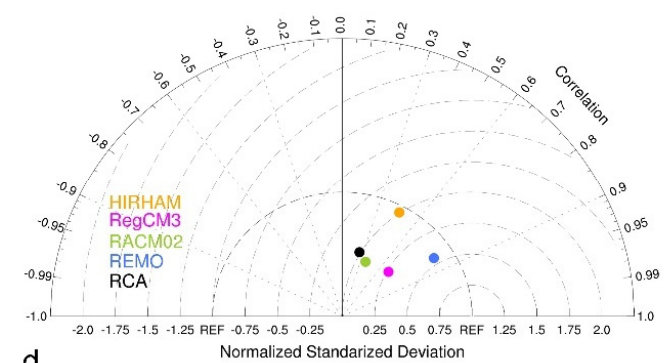

d Normalized Standarized Deviatio

ANN

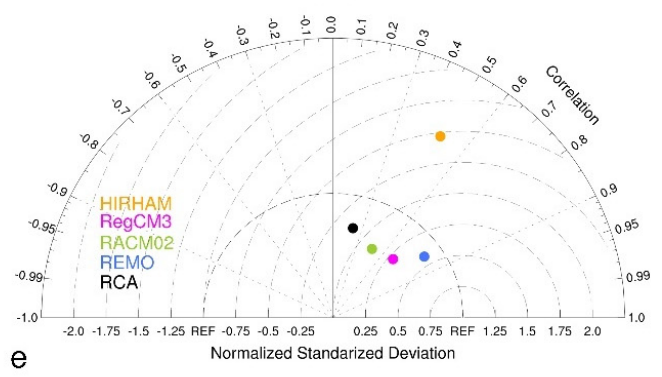

Figure 2. Taylor diagrams displaying a statistical comparison of RCMs and observation of the (a) winter, (b) spring, (c) summer, (d) autumn and (e) annual precipitation in the study area.

Moreover, the RMSE and MAE were used as statistical indexes for evaluating the model's performance. In spite of their arithmetic similarity with the standard deviation, these two statistics are conceptually quite different: the RMSE and MAE are dispersions around a true value and are measures of accuracy that can be used to confirm or deny observation bias. The results of the \%RMSE and \%MAE can be seen in Figure 3.

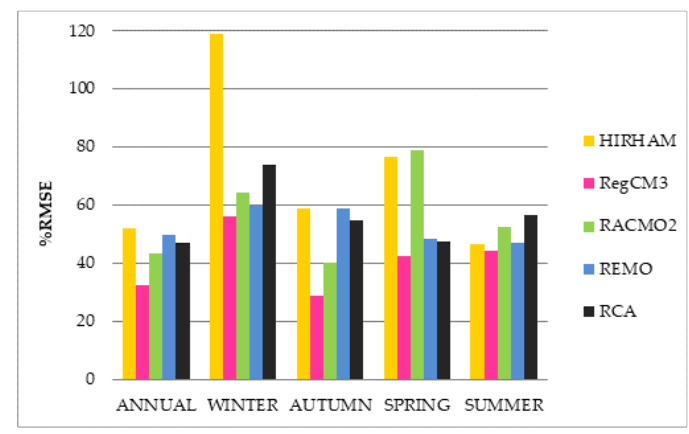

(a)

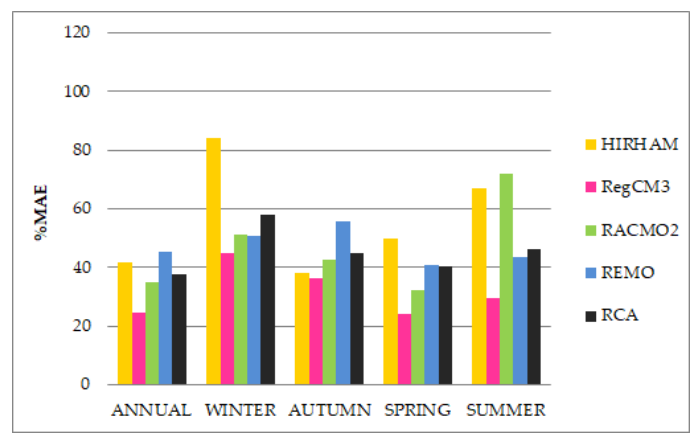

(b)

Figure 3. (a) Percent root mean square error (\%RMSE) and (b) percent mean absolute error (\%MAE) values between simulated and observed annual and seasonal precipitation data in the study area.

Regarding the results of Figure 3, it is obvious that the best simulation was achieved from the RegCM3 model. In the case of winter, the RegCM3 model's effectiveness was found to be poor and the 
results were moderate and less accurate, especially in comparison with autumn and spring. On the other hand, the highest values of RMSE and MAE were found for the HIRHAM model. In addition, relatively high values of errors were also estimated for annual and autumn precipitation by the REMO model, for winter by the RCA model, and for spring and summer by the RACMO2 model.

To this end, the effect of future climate change on annual and seasonal precipitation was studied comparing the baseline period (1974-2000) with the future (2074-2100) precipitation simulation of the most accurate model (RegCM3).

The analysis of the future changes in the precipitation regime showed significant decrease of the amount of precipitation. The graphical representation of the results can be seen in the following figure (Figure 4).

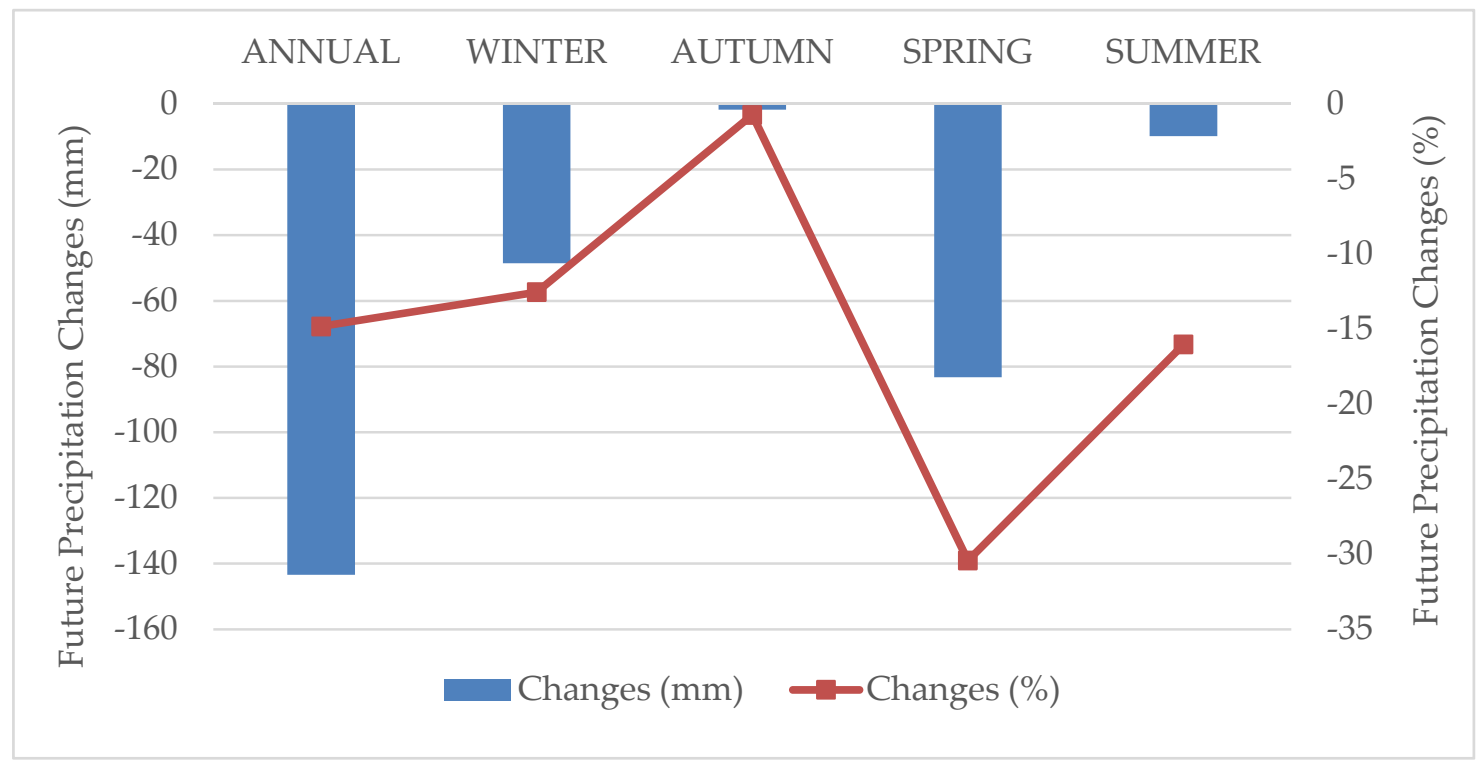

Figure 4. Future changes of annual and seasonal precipitation using the RegCM3 model.

The highest percentage change, taking into account all grid points, was found in spring (30\%), while annual winter and summer precipitation had almost the same percentage of decrease, around 15\%. On the other hand, autumn precipitation seems to be stable until the end of the 21st century.

\section{Discussion and Conclusions}

Precipitation is one of the most important meteorological parameters with significant spatial and temporal variation. Nowadays, there is an urgent need for reliable future climate projections for rational catchment management and infrastructure projects scheduling. The most modern tool for simulating future climate conditions is the regional climate models (RCMs). However, before using climate simulation from dynamic downscaling, it is appropriate to evaluate their performance at different past spatial scales.

In the present study, the performance of five RCMs from the European project ENSEMBLE were evaluated in simulating annual and seasonal precipitation over the mountainous range of Pindus (Central Greece).

The results highlighted that RCMs lack the ability to represent temporal variability of precipitation time series, with the exception of the REMO model. In addition, concerning the model's prediction accuracy, it was found that better simulation was achieved for spring and autumn precipitation. The results were in agreement with similar studies in the Mediterranean basin $[57,58]$. Comparison between models showed that the RegCM3 model had the smaller errors. It was also suggested that finer spatial resolution RCMs of the EURO-CORDEX project better simulated precipitation over complex terrain areas [59]. 
Regarding the future precipitation regime, based on the RegCM3 model, a decrease of precipitation is expected both annually and seasonally until the end of the 21st century. Similar results were also reported in other studies in the Mediterranean basin [14,16,23,26]; however, these studies referred to lowland areas. On the contrary, in Central Europe, even though annual precipitation is projected to increase up to $+10 \%$, RCMs project a significant decrease of precipitation in summer [60].

Over the mountainous range of Central Pindus, the higher decrease of precipitation is expected in spring (30\%), while in autumn, the accumulated precipitation will stay close to the current values. As for the annual precipitation in the summer and the winter, a future decrease of precipitation around $15 \%$ was found. These will favor the development of aridity phenomena in crucial mountainous ecosystems and probably effect biodiversity and water production. The findings of the current study contributed to the rational water resources management and infrastructure work scheduling based not only in current, but also future conditions. The decrease of future precipitation has to be considered by decision makers, and water reservoirs must be planed, especially in mountainous regions where there is excess water, especially in the winter and autumn months. It is suggested that similar research should be done in other mountainous Greek regions; the analysis should also include more factors of the hydrological cycle, such as temperature, humidity, wind, and snowfall, as well as a study of the associated changes in future atmospheric circulation [61]. Moreover, the examination of simulating finer timescale (e.g., daily, hourly) could raise significant conclusions on the effect of climate change on hydrometeorological hazards.

Author Contributions: S.S. collected the rain gauge and RCMs data and wrote the paper; S.D. performed the statistical analysis, while D.S. supervised the research. All authors have read and agreed to the published version of the manuscript.

Funding: This research received no external funding.

Acknowledgments: Data have been provided through the ENSEMBLES data archive (http://ensembles-eu. metoffice.com/), funded by the European Commission (Contact Number GOCE-CT-2003-505539). The authors would like to express their gratitude to the Assistant Konstantia Tolika and Associate Theodoros Mavromatis for their constructive comments and guidance during the data processing.

Conflicts of Interest: The authors declare no conflict of interest.

\section{References}

1. Beran, A.; Hanel, M.; Nesládková, M.; Vizina, A. Increasing water resources availability under climate change. Procedia Eng. 2016, 162, 448-454. [CrossRef]

2. Gosling, S.N.; Arnell, N.W. A global assessment of the impact of climate change on water scarcity. Clim. Chang. 2016, 134, 371-385. [CrossRef]

3. Tsiros, I.X.; Nastos, P.; Proutsos, N.D.; Tsaousidis, A. Variability of the aridity index and related drought parameters in Greece using climatological data over the last century (1900-1997). Atmos. Res. 2020, 240, 104914. [CrossRef]

4. Alamanos, A.; Latinopoulos, D.; Papaioannou, G.; Mylopoulos, N. Integrated hydro-economic modeling for sustainable water resources management in data-scarce areas: The case of lake Karla watershed in Greece. Water Resour. Manag. 2019, 33, 2775-2790. [CrossRef]

5. Longobardi, A.; Buttafuoco, G.; Caloiero, T.; Coscarelli, R. Spatial and temporal distribution of precipitation in a Mediterranean area (southern Italy). Environ. Earth Sci. 2016, 75, 189. [CrossRef]

6. Stefanidis, S.; Stathis, D. Spatial and temporal rainfall variability over the Mountainous Central Pindus (Greece). Climate 2018, 6, 75. [CrossRef]

7. Tolika, K. On the analysis of the temporal precipitation distribution over Greece using the Precipitation Concentration Index (PCI): Annual, seasonal, monthly analysis and association with the atmospheric circulation. Theor. Appl. Climatol. 2019, 137, 2303-2319. [CrossRef]

8. IPCC. Climate change 2013: The physical science basis. In Contribution of Working Group I to the Fifth Assessment Report of the Intergovernmental Panel on Climate Change; Cambridge University Press: Cambridge, UK, 2013. 
9. Giorgi, F.; Lionello, P. Climate change projections for the Mediterranean region. Glob. Planet. Chang. 2008, 63, 90-104. [CrossRef]

10. Arnell, N.W.; Goslin, S.N. The impacts of climate change on river flood risk at the global scale. Clim. Chang. 2016, 134, 387-401. [CrossRef]

11. Li, Z.; Fang, H. Impacts of climate change on water erosion: A review. Earth-Sci. Rev. 2016, 163, $94-117$. [CrossRef]

12. Stefanidis, S.; Stathis, D. Effect of climate change on soil erosion in a mountainous Mediterranean catchment (Central Pindus, Greece). Water 2018, 10, 1469. [CrossRef]

13. Tzabiras, J.; Loukas, A.; Vasiliades, L. A hybrid downscaling approach for the estimation of climate change effects on droughts using a geo-information tool. Case study: Thessaly, Central Greece. Open Geosci. 2016, 8, 728-746. [CrossRef]

14. Paparrizos, S.; Maris, F.; Weiler, M.; Matzarakis, A. Analysis and mapping of present and future drought conditions over Greek areas with different climate conditions. Theor. Appl. Climatol. 2018, 131, 259-270. [CrossRef]

15. Blanc, E.; Reilly, J. Approaches to assessing climate change impacts on agriculture: An overview of the debate. Rev. Environ. Econ. Policy 2017, 11, 247-257. [CrossRef]

16. Koufos, G.C.; Mavromatis, T.; Koundouras, S.; Jones, G.V. Response of viticulture-related climatic indices and zoning to historical and future climate conditions in Greece. Int. J. Climatol. 2018, 38, 2097-2111. [CrossRef]

17. Kalabokidis, K.; Palaiologou, P.; Gerasopoulos, E.; Giannakopoulos, C.; Kostopoulou, E.; Zerefos, C. Effect of climate change projections on forest fire behavior and values-at-risk in southwestern Greece. Forests 2015, 6, 2214-2240. [CrossRef]

18. Kotroni, V.; Cartalis, C.; Michaelides, S.; Stoyanova, J.; Tymvios, F.; Bezes, A.; Georgiev, C. DISARM Early Warning System for Wildfires in the Eastern Mediterranean. Sustainability 2020, 12, 6670. [CrossRef]

19. Michailidou, A.V.; Vlachokostas, C.; Moussiopoulos, N. Interactions between climate change and the tourism sector: Multiple-criteria decision analysis to assess mitigation and adaptation options in tourism areas. Tour. Manag. 2016, 55, 1-12. [CrossRef]

20. Dogru, T.; Marchio, E.A.; Bulut, U.; Suess, C. Climate change: Vulnerability and resilience of tourism and the entire economy. Tour. Manag. 2019, 72, 292-305. [CrossRef]

21. Stathis, D.; Myronidis, D. Principal component analysis of precipitation in Thessaly region (Central Greece). Glob. Nest J. 2009, 11, 467-476.

22. Su, Y.; Zhao, C.; Wang, Y.; Ma, Z. Spatiotemporal Variations of Precipitation in China Using Surface Gauge Observations from 1961 to 2016. Atmosphere 2020, 11, 303. [CrossRef]

23. Tolika, K.; Maheras, P.; Vafiadis, M.; Flocas, H.A.; Arseni-Papadimitriou, A. Simulation of seasonal precipitation and raindays over Greece: A statistical downscaling technique based on artificial neural networks (ANNs). Int. J. Climatol. A J. R. Meteorol. Soc. 2007, 27, 861-881. [CrossRef]

24. Tolika, K.; Anagnostopoulou, C.; Maheras, P.; Vafiadis, M. Simulation of future changes in extreme rainfall and temperature conditions over the Greek area: A comparison of two statistical downscaling approaches. Glob. Planet. Chang. 2008, 63, 132-151. [CrossRef]

25. Petrucci, O.; Papagiannaki, K.; Aceto, L.; Boissier, L.; Kotroni, V.; Grimalt, M.; Llasat, M.C.; Llasat-Botija, M.; Rosselló, J.; Pasqua, A.A.; et al. MEFF: The database of Mediterranean flood fatalities (1980 to 2015). J. Flood Risk Manag. 2019, 12, e12461. [CrossRef]

26. Zanis, P.; Katragkou, E.; Ntogras, C.; Marougianni, G.; Tsikerdekis, A.; Feidas, H.; Anadranistakis, E.; Melas, D. Transient high-resolution regional climate simulation for Greece over the period 1960-2100: Evaluation and future projections. Clim. Res. 2015, 64, 123-140. [CrossRef]

27. Schmidli, J.; Frei, C.; Vidale, P.L. Downscaling from GCM precipitation: A benchmark for dynamical and statistical downscaling methods. Int. J. Climatol. A J. R. Meteorol. Soc. 2006, 26, 679-689. [CrossRef]

28. Sachindra, D.A.; Ahmed, K.; Rashid, M.M.; Shahid, S.; Perera, B.J.C. Statistical downscaling of precipitation using machine learning techniques. Atmos. Res. 2018, 212, 240-258. [CrossRef]

29. Rummukainen, M. State-of-the-art with Regional Climate Models. Wiley Interdiscip. Rev. Clim. Chang. 2010, 1, 82-96. [CrossRef]

30. Xue, Y.; Janjic, Z.; Dudhia, J.; Vasic, R.; De Sales, F. A review on regional dynamical downscaling in intraseasonal to seasonal simulation/prediction and major factors that affect downscaling ability. Atmos. Res. 2014, 147, 68-85. [CrossRef] 
31. Senent-Aparicio, J.; Pérez-Sánchez, J.; Carrillo-García, J.; Soto, J. Using SWAT and Fuzzy TOPSIS to assess the impact of climate change in the headwaters of the Segura River Basin (SE Spain). Water 2017, 9, 149. [CrossRef]

32. D'Oria, M.; Tanda, M.G.; Todaro, V. Assessment of Local Climate Change: Historical Trends and RCM Multi-Model Projections Over the Salento Area (Italy). Water 2018, 10, 978. [CrossRef]

33. Giménez, P.O.; García-Galiano, S.G. Assessing regional climate models (RCMs) ensemble-driven reference evapotranspiration over Spain. Water 2018, 10, 1181. [CrossRef]

34. Tien Thanh, N. A Proposal to Evaluate Drought Characteristics Using Multiple Climate Models for Multiple Timescales. Climate 2018, 6, 79. [CrossRef]

35. Venetsanou, P.; Anagnostopoulou, C.; Loukas, A.; Voudouris, K. Hydrological impacts of climate change on a data-scarce Greek catchment. Theor. Appl. Climatol. 2020. [CrossRef]

36. Venetsanou, P.; Anagnostopoulou, C.; Loukas, A.; Lazoglou, G.; Voudouris, K. Minimizing the uncertainties of RCMs climate data by using spatio-temporal geostatistical modeling. Earth Sci. Inform. 2019, 12, 183-196.

37. Anagnostopoulos, G.G.; Koutsoyiannis, D.; Christofides, A.; Efstratiadis, A.; Mamassis, N. A comparison of local and aggregated climate model outputs with observed data. Hydrol. Sci. J. 2010, 55, 1094-1110. [CrossRef]

38. Koutsoyiannis, D.; Efstratiadis, A.; Georgakakos, K.P. Uncertainty assessment of future hydroclimatic predictions: A comparison of probabilistic and scenario-based approaches. J. Hydrometeorol. 2007, 8, 261-281. [CrossRef]

39. Koutsoyiannis, D.; Efstratiadis, A.; Mamassis, N.; Christofides, A. On the credibility of climate predictions. Hydrol. Sci. J. 2008, 53, 671-684. [CrossRef]

40. Herrera, S.; Fita, L.; Fernández, J.; Gutiérrez, J.M. Evaluation of the mean and extreme precipitation regimes from the ENSEMBLES regional climate multimodel simulations over Spain. J. Geophys. Res. Atmos. 2010, 115, D21. [CrossRef]

41. Soares, P.M.; Cardoso, R.M.; Miranda, P.M.; Viterbo, P.; Belo-Pereira, M. Assessment of the ENSEMBLES regional climate models in the representation of precipitation variability and extremes over Portugal. J. Geophys. Res. Atmos. 2012, 117, D7. [CrossRef]

42. Feldmann, H.; Schädler, G.; Panitz, H.J.; Kottmeier, C. Near future changes of extreme precipitation over complex terrain in Central Europe derived from high resolution RCM ensemble simulations. Int. J. Climatol. 2013, 33, 1964-1977. [CrossRef]

43. Paparrizos, S. The effect of climate on the hydrological regime of selected Greek areas with different climate conditions. Ph.D. Thesis, Faculty of Environment and Natural Resources, Albert-Ludwigs-University, Freiburg im Breisgau, Germany, Breisgau, Germany, 2016.

44. Lazoglou, G.; Anagnostopoulou, C.; Skoulikaris, C.; Tolika, K. Bias correction of climate model's precipitation using the copula method and its application in river basin simulation. Water 2019, 11, 600. [CrossRef]

45. Camera, C.; Bruggeman, A.; Hadjinicolaou, P.; Michaelides, S.; Lange, M.A. Evaluation of a spatial rainfall generator for generating high resolution precipitation projections over orographically complex terrain. Stoch. Environ. Res. Risk Assess. 2017, 31, 757-773. [CrossRef]

46. Alexandersson, H.A. Homogeneity Test Applied to Precipitation Data. Int. J. Climatol. 1986, 6, 661-675. [CrossRef]

47. Haugen, J.E.; Haakenstad, H. Validation of HIRHAM version 2 with $50 \mathrm{~km}$ and $25 \mathrm{~km}$ resolution. Regclim. Gen. Tech. Rep. 2006, 9, 159-173.

48. Jacob, D.; Bärring, L.; Christensen, O.B.; Christensen, J.H.; de Castro, M.; Déqué, M.; Giorgi, F.; Hagemann, S.; Hirschi, M.; Jones, R.; et al. An inter-comparison of regional climate models for Europe: Model performance in present-day climate. Clim. Chang. 2007, 81, 31-52. [CrossRef]

49. Lenderink, G.; van den Hurk, B.; van Meijgaard, E.; van Ulden, A.; Cuijpers, H. Simulation of Present-Day Climate in RACHMO2: First Results and Model Developments; Report TR-252; Royal Netherlands Meteorological Institute: De Bilt, The Netherlands, 2003.

50. Jacob, D. A note of the simulation of the annual and inter-annual variability of the water budget over the Baltic Sea drainage basin. Meteorol. Atmos. Phys. 2001, 77, 61-73. [CrossRef] 
51. Kjellström, E.; Barring, L.; Gollvik, S.; Hansson, U.; Jones, C.; Samuelsson, P.; Rummukainen, M.; Ullerstig, A.; Willén, U.; Wyser, K. A 140-Year Simulation of European Climate with the New Version of the Rossby Centre Regional Atmospheric Climate Model (RCA3); Reports Meteorology and Climatology; SMHI: Norrkoping, Sweden, 2005; Volume 55, p. 108.

52. Taylor, K.E. Summarizing multiple aspects of model performance in a single diagram. J. Geophys. Res. 2001, 106, 2156-2202. [CrossRef]

53. Willmott, C.J.; Matsuura, K. Advantages of the mean absolute error (MAE) over the root mean square error (RMSE) in assessing average model performance. Clim. Res. 2005, 30, 79-82. [CrossRef]

54. Chai, T.; Draxler, R. Root mean square error (RMSE) or mean absolute error (MAE)?-Arguments against avoiding RMSE in the literature. Geosci. Model Dev. 2014, 7, 1247-1250. [CrossRef]

55. Yang, Y.; Zhao, C.; Sun, L.; Wei, J. 2 Improved aerosol retrievals over complex regions using NPP Visible Infrared Imaging Radiometer Suite observations. Earth Space Sci. 2019, 6, 629-645. [CrossRef]

56. Mavromatis, T. Spatial resolution effects on crop yield forecasts: An application to rainfed wheat yield in north Greece with CERES-Wheat. Agric. Syst. 2016, 143, 38-48. [CrossRef]

57. Gallardo, C.; Arribas, A.; Prego, J.A.; Gaertner, M.A.; De Castro, M. Multi-year simulations using a regional-climate model over the Iberian Peninsula: Current climate and doubled CO2 scenario. Q. J. R. Meteorol. Soc. 2001, 127, 1659-1681.

58. Bergant, K.; Belda, M.; Halenka, T. Systematic errors in the simulation of European climate (1961-2000) with RegCM3 driven by NCEP/NCAR reanalysis. Int. J. Climatol. 2007, 27, 455-472. [CrossRef]

59. Tolika, K.; Anagnostopoulou, C.; Velikou, K.; Vagenas, C. A comparison of the updated very high resolution model RegCM3_10km with the previous version RegCM3_25km over the complex terrain of Greece: Present and future projections. Theor. Appl. Climatol. 2016, 126, 715-726. [CrossRef]

60. Kling, H.; Fuchs, M.; Paulin, M. Runoff conditions in the upper Danube basin under an ensemble of climate change scenarios. J. Hydrol. 2012, 424, 264-277. [CrossRef]

61. Dafis, S.; Lolis, C.J.; Houssos, E.E.; Bartzokas, A. The atmospheric circulation characteristics favouring snowfall in an area with complex relief in Northwestern Greece. Int. J. Climatol. 2016, 36, 3561-3577. [CrossRef]

(C) 2020 by the authors. Licensee MDPI, Basel, Switzerland. This article is an open access article distributed under the terms and conditions of the Creative Commons Attribution (CC BY) license (http://creativecommons.org/licenses/by/4.0/). 